\title{
THE EVOLUTION OF INSTITUTIONS IN TRANSITION
}

\author{
Franz GATZWEILER AND KONRAD HAGEDORN
}

CEESA Discussion Paper No. 4/10/2001

ISSN 1616-9166

\begin{abstract}
This paper aims at explaining the role and importance of the evolution of institutions for sustainable agri-environments during the transition process by referring to examples of agri-environmental problems faced in Central and Eastern European countries. It is often stated that the replacement of institutional structures in post socialist countries would bring a unique opportunity to implement new policies and institutions needed to ensure that economic growth is environmentally sustainable. This idea stems from the assumption that the breakdown of the socialist system resembles that (of the Schumpeterian $\square_{\text {type }}$ ) of creative destruction - a process that incessantly revolutionizes economic structures from within. However, not all kinds of institutions, especially at local level, can simply be implemented, and even more, not incessantly. Instead, they evolve as a response to ecosystem and social system characteristics, and this is a rather slow process. A central question therefore is whether the required institutional arrangements for achieving sustainability in the area of agrienvironmental resource management can be built more easily in periods of transition as they fill institutional gaps, or whether processes of transition make institution building a more difficult and far more time consuming task than previously thought. Above all, we want to find out, how these two processes of institution building at different scales affect the sustainable management of resources such as water and biodiversity in agriculture? It will become clear that the agrienvironmental problem areas faced during transition are complex and dynamic and require adequate institutions both by political design and from the grassroots, to be developed by the respective actors involved. Transition from centrally planned to pluralistic systems has to be considered as a particular and in some respect non-typical process of institutional change. Popular theories of institutional change do not necessarily apply. The privatisation experience from many CEE countries will serve as an example. Finally, we will provide some examples of missing or insufficient interaction between political actors or agencies and people in CEE countries. Substantial investments into social and human capital, particularly regarding informal institutions are needed for institutions of sustainability to evolve.
\end{abstract}

\footnotetext{
${ }^{1}$ Schumpeter (1942)
} 


\section{Franz Gatzweiler}

is presently coordinating the CEESA (Sustainable Agriculture in Central and Eastern European Countries) research project at the Humboldt University of Berlin, Germany. His background is in agricultural economics with a specialisation in international agricultural development. His research interests are institutional economics and the economic valuation of ecosystem functions.

Contact: franz.gatzweiler@agrar.hu-berlin.de

\section{Konrad Hagedorn}

is professor for Resource Economics, Head of the Chair of Resource Economics and Director of the Berlin Institute of Co-operative Studies. Prof. Hagedorn has outstanding experience in agricultural and environmental policy research and political economy studies and concentrates on the combination of institutional economics, environmental policies and transformation issues. His research includes CAP reform processes and is oriented to integrate political actors such as political agencies and interest groups.

Contact: k.hagedorn@agrar.hu-berlin.de

CEESA Discussion Papers are reports prepared by members of the CEESA research network or external authors working on similar topics. The papers have received limited reviews. Views and opinions expressed do not necessarily represent those of the CEESA research project. Comments are highly welcome and should be sent directly to the authors. 
Content

1 Institutions, Ecosystems and Sustainability - A Framework ................................. 4

2 Property Rights Regimes and Governance Structures for Agri-environmental

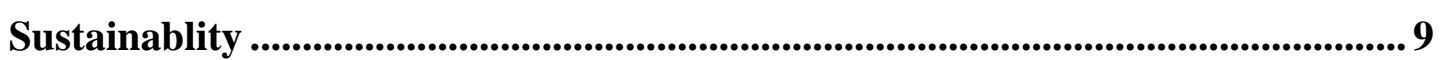

3 Particularities of Institutional Change in Transition Countries ............................ 16

4 Special Problems of Building Institutions of Sustainability in Transition

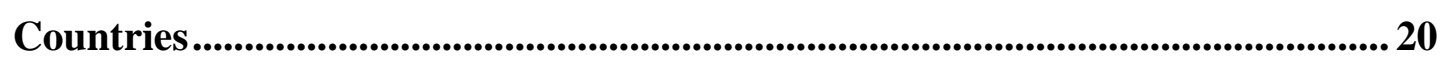

5 Social Capital and Public Participation in Transition Countries..........................22

6 Bridging the Gap between Politics and People ........................................................... 27

7 Conclusions...........................................................................................................................................33

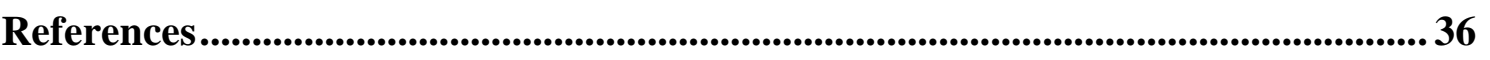




\section{Institutions, Ecosystems and Sustainability - A Framework}

Institutions are sets of interrelated rules governing given aspects of social life which are acknowledged (or even sanctioned) by all or some members of society. Institutions regulate relationships among individuals and between social and the ecological system, i.e. rights and duties as well as costs and benefits of actions, and therefore institutions are the essential linkage between social and ecological systems (Goglio, 1997; Ostrom et al., 1993; Gatzweiler et al., 2001). In the following, a framework focussing on the interaction of social and ecological systems will be introduced. The notion of evolution and co-evolution refers to the characteristics of the process of (intentional) institution building or (non-intentional) institutional change as a process which is dynamic (i.e., it changes in time), complex and a result of co-adapting social and ecological systems. After a short description of the ecological system, the functions it provides for human use and the institutions which evolve as response, we will characterise the social and cultural system as being just as important for the evolution of institutions at the interface of social and ecological systems.

Nature is intrinsically interwoven with man's institutions. To isolate man from nature or ecology from the economy is probably one of the weirdest undertakings of past and present times (Polanyi, 1944). The destructive and sometimes catastrophic results of a mismatch between institutions and ecosystems or an absence of institutions is evident in many resource management problems which lack adequate coordinative response from the social systems. Often 'natural catastrophes' such as landslides or floods (Picture 1) are not as 'natural' as they may appear at first glance. Impacts and changes of the ecosystems can lead to disasters which might have been prevented if better knowledge of the functions which ecosystems provide would have been available. Environmental media like water, soil and biodiversity are part of complex ecological cause-effect chains. Changes of these ecological patterns and its interlinkages are often unpredictable, especially in the long term. The predictability of ecological change is further complicated by the fact that the determinants of change are largely unknown and change over time. 
Picture 1: Flood Along the Tisza River, Hungary/Ukraine Geographers believe that a significant factor in the worsening flooding is because of tree clearing in Ukraine in the catchment area of the upper Tisza.

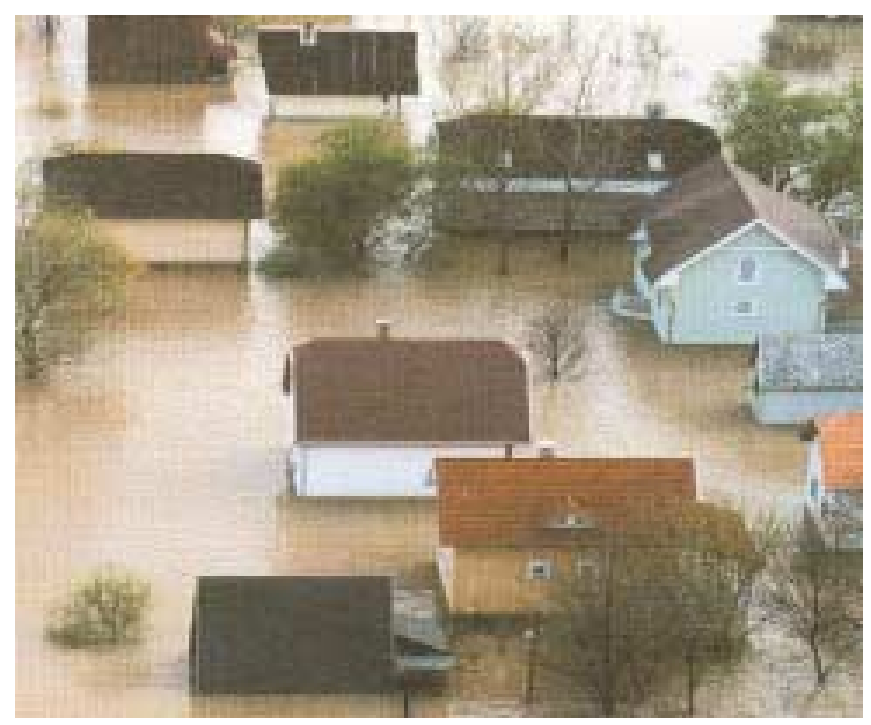

Source: MTI, Hungary

Agriculture has traditionally been operating at the interface of social and ecological systems, and farmers have developed specialized skills to manage the environmental functions provided by the ecosystem. Complexity and dynamics are also characteristics of social systems, and the predictability of social change is just as difficult as that of ecological change. Particularly in economics, we are just beginning to understand that human behaviour is far more complex than merely rational and self-interest driven. Both the social and the ecological system are embedded in larger systems and also contain further systems on different scales. Ultimately, as information on system characteristics increases, the border line between human and ecological systems is less easy to define, and it becomes obvious that human and ecological systems are intrinsically interwoven. This is particularly true for agriculture. The story of the origins of agriculture is a story of development; and the story of development is a story of the victory of man against nature. Ever since the dominant understanding of development was to restrain and to maintain control over ecosystem complexity by the efficient use of some very few ecosystem functions. The institutional structures to facilitate the efficient exploitation were mainly built on private property regimes. After more than one century of fast technical progress and high economic growth, however, we need to concentrate our efforts on making use of ecosystem functions, instead of replacing/destroying them, in order not to 
deprive future generations from benefiting from essential functions of nature. This process reflects the co-evolution between social and ecological systems.

In this context, our understanding of sustainability refers to the ways social systems interact with and relate to ecological systems by means of their institutions. Sustainable social or ecological systems are systems which can persist their integrity and functionality over time, and this dynamic process is accompanied by the establishment of institutions which facilitate co-adaptive change. A special attribute of sustainability is that both systems are interlinked and therefore need to sustain each other in order to sustain themselves. Ultimately this is a question of existence. Without ecology there is no economy, and without economy there is no existence (Hannon, 1997). From a biological point of view sustainability means that the resource avoids extinction. In economic terms it means that humans avoid major disruptions and can hedge against instabilities. Causes for the mismanagement of natural resources tend to be associated with absent institutions or with mismatches among institutions. Often institutions do not exist at the appropriate scale, or they are ineffective because they fail to control ecosystem stocks and flows properly. Other reasons for scale mismatches are ineffective decision making linkages or that decisions are based on information aggregated at the wrong scale, even though information at the appropriate scale may exist. There is considerable information on ecosystems at the small scale. However, large-scale systems are not simply smallscale systems grown large. Management systems that work well in handling traditional resource problems at local level can produce destructive results when applied to global system scales. Similarly, if local resource management systems are superseded by national or international regulations, local ecosystems frequently suffer mismanagement (Costanza et al., 2001).

The task of creating institutions of sustainability actively/intentionally or allowing for the creation of institutions passively/unintentionally means establishing compatibility between ecosystems and social systems by matching the requirements of ecosystem function management with adequate property rights regimes (rules) and appropriate governance structures (arrangements). This is because specific ecosystem characteristics require specific institutions to make use of the functions provided by the ecosystem and to protect it simultaneously from degradation or pollution. The network pattern of con- 
nectivity within and between social and ecological systems plays an important role for designing institutions for sustainable resource use because it makes it difficult to arrive at the desired institutional structure. Only to a certain degree we are able to intentionally design both social and ecological systems due to the complexity of the desired outcomes. Institutional framing conditions supporting and allowing for the evolution of local resource management institutions belong to this type of institutions which can (and should) be designed intentionally. However, as the nature of ecosystem characteristics is also stochastic and unpredictable (to a certain degree), the final match between ecosystem structures and appropriate governance structures will only occur, if at least some of these institutional innovations are given adequate scope of action to evolve spontaneously and unintentionally. Some institutions regulating human action evolve without conscious human design and maintain themselves without any formal 'machinery' for enforcing them (Sugden, 1989). 'People do things in a certain way because that's what they have been always doing and it has proven to be the right way to do things'. The evolution of such institutions as a response to ecosystem specificity consists of processes of co-adaptation whereby structures are progressively modified to give better performance. These evolutionary processes of co-adaptation can only work along the lines of communication, information, feedback and response. For this processes of co-adaptation to be successful political actors should care for both reliable framing conditions by some basic rules and arrangements and sufficient scope for learning-by-doing and self-governance

\footnotetext{
${ }^{2}$ The crux of the problem for the process of organisation, and institutional building is that initially actors at both the political and local level have incomplete information about which structures are appropriate. Initially, they do not have experience from similar situations in the past. To reduce this uncertainty, observation and explorative description are unavoidable. Learning from trial and error is unavoidable for this initial phase. Holling et al. (1996) who investigated the role of adaptation in social and ecological systems come to the grim conclusion that human systems of property rights built around deterministic ecosystem models are not flexible in their application or crafted in light of the temporal or special demands of natural systems. Until modern human institutions are built on ecological dynamism, and designed to flex with natural variability, their principle impact will be to impede nature, not to sustain it.
} 
Fig. 1: Institutions are a Co-evolutionary Product of Interacting Social and Ecological Systems - A Framework for Analysis

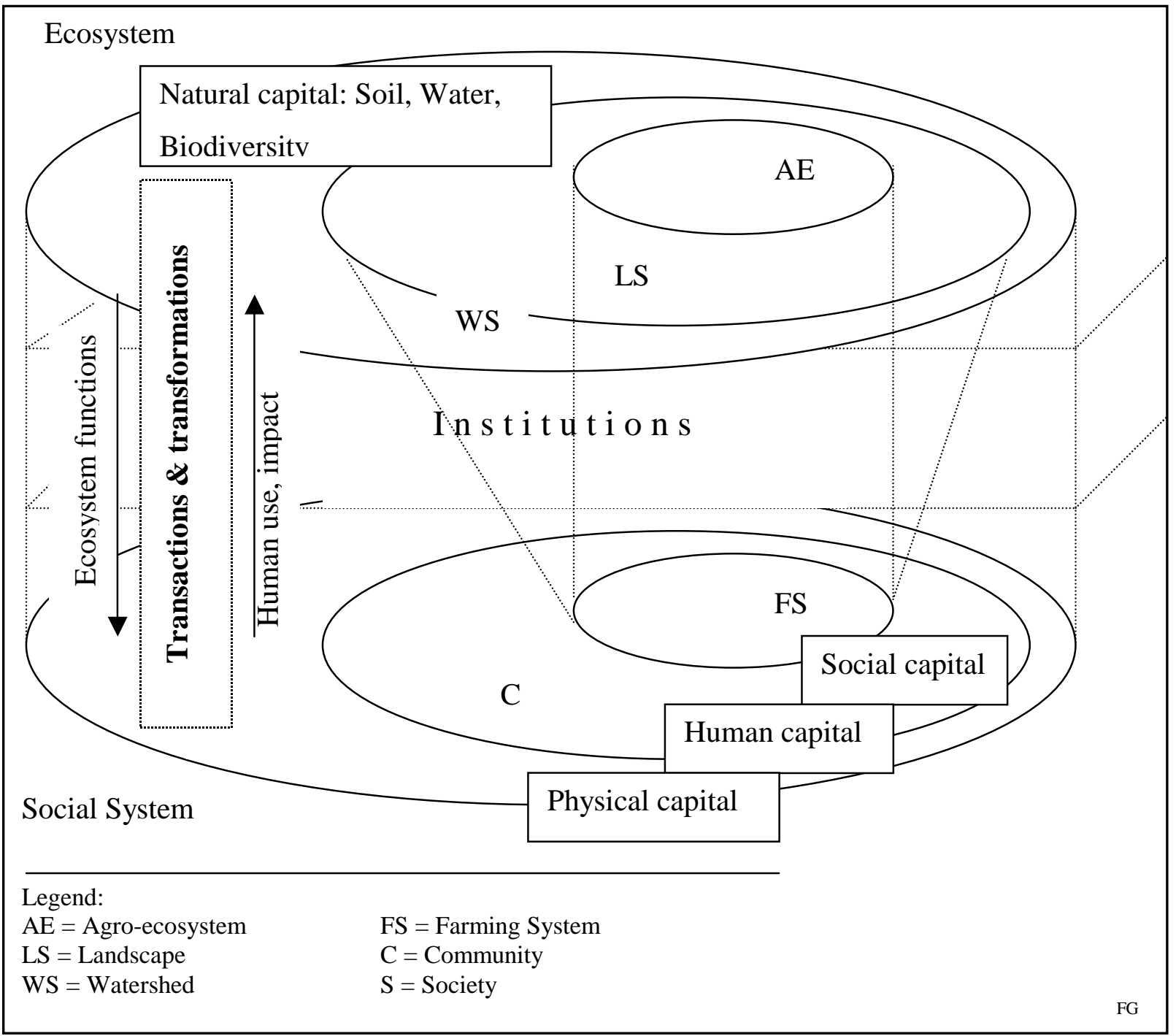

As a consequence, institution building is a dynamic and complex process involving

(1) the capital stocks in social and ecological systems (actors, human-made capital and natural capital such as biodiversity, water, etc.) and their characteristics,

(2) the transactions and transformations ${ }^{3}$ between individuals or groups and between the social and ecological system and their characteristics,

\footnotetext{
${ }^{3}$ Transactions are exchange relationships of material assets or information between actors of the social system and the ecological system. Transformations are physical changes of inputs into outputs, e.g. consumption and production processes

$8 \quad$ Sustainable Agriculture in Central and Eastern European Countries (CEESA)


(3) sets of rules, norms, property rights and regulations that control social and ecological system behaviours (e.g., temperature controls in ecological systems, rules in social systems) and

(4) the governance structures in which the rules are organised.

Whereas (1) - (3) are features of both, social and ecological systems, (4) is an aggregate level of (3) and only occurs in social systems. The question now arises as to how such a rather general framework can be applied to concrete problems such as the evolution of institutions for agri-environmental sustainability.

Table 1: The Logic of Institutional Change for Agri-environmental Co-ordination

\section{Interaction between nature and actors}

Properties of transactions

Characteristics of actors
Institutions of environmental sustainability

Property rights on ecosystem functions/ecological attributes

\section{Institutional Performance}

Governance structures for agri-environmental relations

\section{Property Rights Regimes and Governance Structures for Agri-environmental}

\section{Sustainablity}

Of course, institutions focussing on agri-environmental sustainability are a part of the system of ecological-economic co-evolution with mutual adjustment mechanisms. The forces driving their (non-intentional) evolution or the criteria relevant for their (intentional) design can be derived from the framework developed above. Accordingly, institutional change regarding agri-environmental co-ordination, i.e. mainly the property rights regimes and governance structures in this area, can be understood as a response to technological, ecological and economic factors, on the one hand, and societal, behavioural and political influences, on the other (Table 1). For structuring and analysing the relationships and the interplay between these factors, an explorative concept is necessary. Institutional change in the area of resource protection and agri-environmental co- 
ordination is related on the following groups of phenomena (see, for a more comprehensive description, Hagedorn, 2000a; Hagedorn, et al., 2001a):

(1) Which institutional arrangements arise, that depends on the features and implications of the transactions related to nature and the ecosystem (Box 1). This is mainly influenced by the physical properties and material transformations with which environmental goods and bads, benefits and damages are associated (example: leaching of nitrates into the groundwater on sandy soils). Technological innovation and structural change lead to permanent changes of these properties and transformations.

(2) Simultaneously, institutional change depends on the characteristics and objectives of the actors involved (Box 2) in those transactions. This is not only true for individual actors whose values, interests and resources to exert influence (power) are very different, but also for groups of individuals like communities using organisations and networks to shape institutions according to their objectives (example: farmers who cause nitrate leaching by high nitrogen fertilisation and unfavourable crop rotation without catch crops).

(3) The changes in institutions, which result from the two main categories of driving forces mentioned above, affect the design and distribution of property rights on ecosystem functions (DeGroot, 1992) (Box 3), or more precisely, on those cost and benefit streams which can be attributed to natural capital and ecosystem services (example: trade-offs between reducing nitrogen balances by means of lower fertilisation and intercropping and decline in gross margins). The property rights can be defined for numerous ecological properties of a physical piece of nature, each of them related to particular costs and benefits (and for each of these differentiated rights components, the institutional design of the right or duty can differ: private, collective and state property regimes or open access). They tend to become more and more differentiated, because they do not only apply to physical goods like land, but also to various dimensions and many details of land use relevant to environmental protection and sustainable agriculture, e.g., the right to decide on crop rotation. 
Box 1: Features of Transactions Affecting the Natural Environment and Ecological Systems

(1) Excludability of actors from access to environmental goods and exclusion costs

(2) Rivalry among the users of environmental, goods, i.e. "subtractability" in common-pool resources

(3) Asset specificity induces opportunistic behaviour: site specificity, capital specificity, specific knowledge

(4) Separability is often low due to jointness of production of environmental goods

(5) Frequency of transactions: specialised governance structures, economies of scale and learning by doing

(6) Uncertainty causes transaction costs for measuring and monitoring and gathering adequate information

(7) Complexity, combined with insufficient scientific knowledge, provokes opportunistic behaviour

(8) Heterogeneity and variability, i.e. "site and situation specificity" makes standardised regulation inefficient

(9) Legitimacy refers to compatibility with the normative views of the actors and groups concerned

(4) Necessarily, such changes in property rights on nature components are accompanied by corresponding changes in governance structures (Box 4), mainly for two reasons: first, property rights on nature components, like other property rights, must be supervised and sanctioned to become effective instead of only being formal in nature; and secondly, the actors can only make use of their rights and entitlements and will only fulfil their duties and obligations, if transactions are organised and co-ordinated (example: farmers will only comply with fertilising restrictions and cropping prescriptions if a adequately working system of measuring and monitoring activities, information and administration, positive and/or negative incentives, i.e. of subsidies and/or penalties, exists). 


\section{Box 2: Characteristics of Actors Involved in Agri-environmental Co-ordination}

(1) Values and beliefs of the actors and their particular attitudes and perceptions of agri-environmental issues

(2) Reputations for reliability and trustworthiness are important for the credibility of their commitments

(3) Resources for influencing agri-environmental strategies at the regional and local levels, i.e. by direct participation

(4) Resources for influencing political decision making at higher than the regional level, in which land users cannot participate directly

(5) Information and knowledge, and capacities for acquiring, processing, retaining and using knowledge and information; asymmetric information

(6) “Actor's method of action selection": maximising homines oeconomici, constrained maximisers with bounded rationality, or fallible learners

(7) Social environment and embeddedness of actors in communities and cultures

(5) Similar to the property rights regimes mentioned above, governance structures are also very differentiated (markets, e.g., tradable pollution quotas, hierarchies such as environmental bureaucracies, hybrid forms like contractual relations, e.g., stewardship contracts, horizontal non-market co-ordination, i.e. co-operation and participation, knowledge and information systems, formal and informal networks, methods and infrastructure for measuring, monitoring and evaluating environmental damages and benefits, e.g., systems of laboratories, rules and procedures for conflict resolution, regulation of liability, incentives to promote innovation and learning, etc.). They may include self-organised co-ordination (e.g., environmental cooperatives) and governmental regulations (e.g., environmental bureaucracies), and they are not only related to the implementation of environmental instruments, but also to decision making on environmental policies which takes place on the different levels of co-operative federalism (community, region, province, national, EU, international). 


\section{Box 3: Property Rights on Ecosystem Functions Related to Agriculture}

(1) Benefit streams or cost components connected with physical goods: differentiated "property rights on nature components"

(2) Property rights separately defined for numerous ecological properties of a physical piece of nature: private, collective, state property regimes, open access

(3) Transaction costs for defining and establishing property rights can be prohibitively high, but may change, for example, by technological progress

(4) Structure of property rights: selecting the most efficient right holder, the "residual claimant", deciding on control rights, "bundling of rights" or "divided property"

(5) Bundling property rights on nature components favours decentralisation, dividing rights results in centralisation and affects motivation and participation

(6) Rights cannot be used and duties cannot be fulfilled in an isolated way in ecological systems, rights and duties are conditional upon the use and fulfilment of other rights and duties respectively

For the last point mentioned above, the political economy behind the process of joint implementation and decision making in a federal system has to be taken into account. This may produce scale problems similar to those emphasised by Constanza et al. (2001): Self-interested or insufficiently informed political actors may be reluctant or unable to create missing linkages between scales and to gather information at appropriate scales.

For exploring and explaining these four groups of variables in more detail, we surely can make use of approaches like New Institutional Economics and the Institutional Analysis of Natural Resources (e.g., Richter and Furobotn, 1996; North, 1992; Williamson, 1996; Ostrom, 1990; 1998; 1999; Bromley, 1991; 1996; 1998; Loehmann and Kilgour, 1998; Berkes and Folke, 1998). Studies available on environmental cooperation and participation are available as an additional source of theoretical concepts and empirical information (see, e.g., OECD, 1998; Bahner, 1996; Zimmer, 1991; 1994a,b; Campbell, 1998; Fisk, Hesterman and Thorborn; 1998; van Woerkum and Aarts, 1998; Woodhill and Roeling, 1998; and the contributions to the $64^{\text {th }}$ EAAE 
Seminar published in Hagedorn, 2001b). However, detailed empirical research of this sort is still in an initial phase, and much has to be done: The number of characteristics of the human actor, features of transactions and types of rules affecting organisational arrangements which affect the capacity of human actors to manage environmental resources is very large, and we are far from complete knowledge about these characteristics and their effects.

In spite of this, we can draw the conclusion that the property rights regimes and governance structures necessary for achieving sustainabilty will not be simple. As they need to evolve in response to the complex, diverse and dynamic nature of the characteristics of the social and ecological system, it appears logical that there can be no single type of rules, norms, rights and governance which would guarantee sustainable development. Bowels and Gintis (2000) support this view by stating that well-designed institutions make different governance structures (e.g., markets, states, communities and cooperative structures) compliments, not substitutes.

How can we adjust our research concepts to the fact that both property rights regimes and governance structures are in a process of change that makes them more complex and diverse? As far as governance structures are concerned, the concept of polycentricity may contribute to an adequate solution. Polycentricity is created by those who participate in it. It is an order which allows communities to organise different kinds of public goods at different scales of aggregation with different and overlapping jurisdictions. It cannot be sustained unless the relevant actors make use of their full range of alternatives. Polycentric order must be grounded in mutually supportive institutional arrangements in the economic, legal, constitutional and political realms. Markets for private goods are needed to provide incentives for efficient production. The producers and providers of public goods and services must have some assurance that their efforts to provide those goods and services to various communities are legally and economically recognized. 
Box 4: Governance Structures for Regional or Local Agri-environmental Coordination

"New Institutional Economics":

- Markets

- Hierarchies

- Hybrid forms

"Institutions of Sustainability":

- Strategies to improve reflexivity

- Self-organisation and participation

- Interest harmonisation and conflict regulation

- Concepts for innovation and learning

“Agri-environmental governance structures":

(1) Market solutions like auctions or tradable quotas

(2) Organisations like environmental bureaucracies

(3) Contractual relations, e.g. stewardship contracts

(4) Horizontal non-market co-ordination, particularly co-operation and participation

(5) Knowledge and information systems, formal and informal networks

(6) Methods and infrastructure for measuring, monitoring and evaluation, e.g. laboratories

(7) Rules and procedures for conflict resolution, distribution of costs and benefits, liability

(8) Incentives and opportunities to promote innovation and learning, establishing a knowledge system

For polycentric orders to operate there must be correspondence between the beneficiaries of public goods and services and those who pay for/provide them (McGinnis, 1999). Polycentricity provides an ideal setting for the co-production and co-management of public goods and services by members of communities. It offers an alternative to the passive expectations people have towards political authorities. Polycentricity may be a helpful concept for solving the agri-environmental problems faced during transition as it enables to connect the loose ends of the requirements for sustainable agri-environments identified later in this paper. This means to establish a link between self-governance of 
citizens and their decentralised institutional choice to the decision-making procedures and implementation capacities of national and EU policy makers.

\section{Particularities of Institutional Change in Transition Countries}

As a matter of fact, the process of institution building for sustainable resource use is affected by the particular procedures and problems arising from the process of transforming the political and economic system. Findings from in three CEE Countries presented by the KATO privatisation studies (Milczarek, 2000; Hanisch, 2000; Schlüter, 2000) have led to the following results (see also Hagedorn, 2000b):

1. "Efficiency and competition" as compared to "distribution and conflict resolution" and "ideology and mental models" are not the main driving forces of privatisation.

2. The process of privatisation should no longer be conceived of as "privatisation" according to its theoretical understanding as establishing merely private property rights.

3. Shared mental models, innovation concepts, learning processes and access to networks, to human and to social capital are important mechanisms for institutional change.

Efficiency could be a driving force of privatisation, because this does not necessarily mean inventing new institutions but just implementing a transfer of institutions. As a consequence, the Theory of Exchange and Competitive Selection as an efficiencyoriented explanation for institutional change might be applicable (Knight, 1992: 106). This approach includes competitive pressure as a selection mechanism for efficient institutions. However, the KATO privatisation studies (Milczarek, 2000; Hanisch, 2000; Schlüter, 2000) provide only little support for this approach. In contrast, the Theory of Bargaining and Distribution considers social institutions "as a by-product of strategic conflict over substantive social outcomes" (Knight, 1992: 107). As pointed out in detail by Hanisch (2000) and Schlüter (2000), this theory focuses on social interaction between actors seeking to achieve their distributional objectives. This is influenced by resource asymmetries of actors, credibility of their commitment, individual risk aversion, time preferences, etc. This approach has primarily been applied to decentralised institutional change, but most of its components also seem to be relevant to institutions which are centrally designed and are also treated by the Public Choice Theory of Institutional Change (Weimer, 1997; Hagedorn, 1991; 1996a,b; 1999). 
However, these observations also show that the process of privatisation driven by the desire of groups of actors having unequal power resources to appropriate "a piece of the cake" often took place in a way that cannot be considered "efficient" for society. This contradicts a conception popular in economics that associates efficiency with private property rights and analogously suggests that "privatisation" in the sense of merely establishing private property rights is equivalent to increasing efficiency.

Property rights theory is often misunderstood as an approach explaining the definition and distribution of disposition rights focussing on physical entities (Hagedorn, 2000a; Hagedorn et al., 2001a). Strictly speaking, actors only attribute (positive or negative) values to a physical good because the right holder is favoured by benefit streams or in case of a duty is burdened by cost components which are connected with the physical good. A natural good, like soil, is usually considered to carry only one homogeneous property title. However, categories of property rights can be separately defined for $\mathbf{n u}$ merous economic or ecological properties connected with the physical piece of nature, each of them related to particular costs and benefits. For each of these differentiated rights components, the institutional design of the right or duty can differ: private, collective and state property regimes are imaginable (or others, more differentiated ones), and also the absence of property rights definition and delineation in the sense of open access (Bromley, 1991; Ostrom, 1990). In addition, property rights on such attributes of natural or physical capital require adequate governance structures, because they must be supervised and sanctioned to become effective instead of only remaining formal in nature.

In other words, concepts of privatisation are only complete and consistent if

- all main attributes of a physical or natural object are subjected either to private property rights or other property rights regimes (or combinations) if these are superior, and if

- governance structures covering each component of this bundle of rights are developed, not neglecting the required societal, political and administrative structures for decision making, participation and implementation. 
The KATO privatisation studies (Milczarek, 2000; Hanisch, 2000; Schlüter, 2000) provide many examples for the problems which arise if decision makers follow the abovementioned misconception of privatisation neglecting property rights regimes and governance structures that are not private. For example, in the Czech Republic private farmers are sanctioned in order to keep their competitiveness and their reputation on the land market low, in Bulgaria land, machine services and the processing industry is monopolised by some actors, and the social situation of former state farm workers in Poland deteriorated. The nature of this problem may be even better illustrated by the experience that privatisation concepts usually neglect environmental protection and ecological sustainability (Lütteken and Hagedorn, 1999). Exploitation of soil fertility and destruction of irrigation equipment as well as degradation of drainage systems during the process of restitution, privatising large livestock units without regulating pollution by manure, etc. show that property rights on nature attributes or ecosystem functions and corresponding governance structures are given low priority in institutional reforms.

When the centrally planned economies collapsed, the shared mental models which had been developed during the socialist system could no longer fulfil its tasks. Individuals and groups depend on meaningful mental models for the purpose of reducing complexity (North, 1990: 24). As a consequence, people were seeking for new cognitive schemata to understand and to explain the world which had changed very much for them. In particular at the beginning of the transformation period, when the system in transition was characterized by a high degree of insecurity, reduction of complexity was urgently needed. Since this basic function of shared mental models is of major relevance in this confusing situation, ideologies have played an important role in transition countries. Although in early stages of the transformation process society as a whole may not have arrived at sufficiently stable shared mental models yet, they may already exist within certain groups, which then can make use of their common understanding of problems for lowering transaction costs of decision making and for facilitating achievement of their particular group objectives. As communication and consensus building is easier and requires less resources within such groups, they become more powerful than others. Another source of gaining power in the privatisation process was the ability of some actors to shape people's shared mental models in the bargaining process regarding new institutional arrangements. 
The above-mentioned privatisation studies have shown that there obviously is a variety of institutional choices for problems of institutional change in general and for transition in particular. However, if actors and groups do not know about the solutions, lack creativity for finding them, do not have sufficient resources to develop and to discuss innovations, cannot communicate new institutional concepts in order to arrive at joint conceptions of the problems, and are not able to organise collective action and participation of stakeholders, then the pure fact that such solutions might exist is of little practical use. Collective learning processes combined with the evolution of new shared mental models seem to play a fundamental role for institutional innovation.

The empirical evidence from privatisation in post socialist countries mentioned in the previous paragraphs, e.g., the misconception of what 'privatisation' should be, show the importance of the wider social context of property regulations. There is particular evidence of what Hann (2000) calls the 'tragedy of the privates' in post-socialist countries privatisation was often carried out under consultation of Western advisers with a rather narrow economic understanding of private property and with a strategy of "privatise now and then let market competition prevail'. Neo-liberalism and privatisation have been prominent in the recipes offered to the ex-socialist countries. This ethnocentric understanding of property relations (the 'European dichotomy', either private or collective) continues to dominate popular academic thinking about property in the ages of the cold war and after the collapse of the Soviet Union ${ }^{1}$ (Hann, 2000).

How helpful is this 'mental model' of privatisation in explaining the new social patterns of the first post-socialist decade? Probably it played an important role shortly after the collapse of the centrally planned economies for reducing insecurity and uncertainty but presumably it does not help very much. In their contrasting ways, the simplifications of the liberal models (privileging economic performance and private ownership) and the socialist models (privileging politic, social justice and collective ownership) cannot do justice to the actually prevailing complexity and social, legal, political and economical

\footnotetext{
${ }^{4}$ Engels (1884) emphasises the importance of an evolutionist approach to property.
} 
embeddedness of property relations in all social systems 5 . Studying the change of institutions in countries in transition must therefore include the enhanced rights and entitlements of not only private, but all types of property rights regimes in these wider domains. The same applies to the heterogeneity of governance structures ${ }^{\text {. }}$.

For these reasons, regardless the framing conditions of the political system, governments should provide sufficient scope of action and adequate incentives for institutional diversity to evolve instead of imposing organisational structures which may not match local circumstances, because the diversity of ecological functions, which require a very specific response from the people involved, are not adequately predictable at other levels of society than at the local level. This does not mean that institution building for sustainable resource use can evolve without favourable framing conditions at the policy level. However, transition and accession policies too often neglect the potentials of institutions outside of state bureaucracy (e.g., networks, cooperatives, new forms of associations, mechanisms of learning, monitoring and communication). If successful strategies are to be put into practice, political instruments will hardly be adequate and useful if the institutional choices made by the people are overlooked (Hagedorn, 2001a; Hagedorn et al., 2001b).

\section{Special Problems of Building Institutions of Sustainability in Transition Coun- tries}

The previous sections have given some explanations why institutional innovation towards sustainability is a very special, complex and not completely predictable process (section 2), and that the fundamental institutional changes taking place in the transition countries also have its own particularities (section 3). As a consequence, the question arises as to what happens if we want to achieve both simultaneously. Is it reasonable to

\footnotetext{
${ }^{5}$ History provides evidence that even the most socialist countries did not disturb individual rights over many items of individual property and most extreme neo-liberal regimes depend heavily on a set of conditions maintained by the state.

${ }^{6}$ Von Benda-Beckmann and von Benda-Beckmann (1999) offer an analytical framework which distinguishes different dimensions of social organisation at which property relations can be studied: cultural and ideological (1), normative and institutional regulations (2), social property relations (3), and social practices (4). 
organise such a "double transformation" at the same time? Let us assume that it is feasi-

ble provided that we take into account the following problems that are likely to arise:

- In the transformation situation, the actors, e.g., farm managers or agricultural bureaucrats, seek opportunities to secure their living and to prepare for a new or continued carrier. To achieve this objective, acquisition of private property rights which provide access to high individual benefits from entitlements and cause only low costs from duties is given priority. Privatised land, machines or cattle belong to this category of assets powerful actors aim at and are able to appropriate, as pointed out in the previous section. In other words, there is a high incentive intensity for institutional change regarding the distribution of private property rights.

- The next aspect refers to the effectiveness of property rights. Developing appropriate governance structures for the profitable use of private property rights is in many cases easier than it is for non-private property rights. Admittedly, establishing markets, e.g., for meat or vegetables, requires considerable innovation and investment, for example, in marketing cooperatives and processing factories, but this is driven by private interests.

- In contrast, governance structures for making effective non-private property rights related to sustainable resource use and agri-environmental sustainability is much more difficult and costly. The first, general reason for this is that the political and administrative system is in a stage of fundamental reform 7 and still has to develop those capacities of decision making and implementation which democratic societies need to work properly. Secondly, and this may be even more important, these governance structures are every costly in terms of social capital (e.g., for consensus building), human capital (e.g., for sustainable farming practices), and physical capital (e.g., for building laboratories to control environmental standards). Probably, these investments in all three types of capital imply a large proportion of dedicated assets with a high degree of specificity.

- Due to these obstacles of implementation and enforcement, including requirements such as monitoring, information, communication, participation, etc., the incentive intensity for non-private property rights is much lower than for private property rights which are more attractive because they will be more or sooner effective in the transition phase. However, there is a second reason for this. Property rights on ecological attributes of the nature components are often duties causing negative income effects, for example, if nitrogen inputs have to be reduced. People in transition countries whose income are often low (and sometimes have even declined in the nineteenth) refuse to accept this, and limited state budgets do not allow for paying compensation for income losses from environmental measures.

- In addition, it appears not only less attractive, but also less necessary to care for institutions of sustainability in the transition period. After 1990, the abolition of input subsidies and the drop of demand for agricultural products (domestic and external) resulted in an unfavourable ratio of input and output prices. As a consequence, both the use of chemical inputs and the production output were declining. Thus, the political changes in 1989/90 and the collapse of the economy reduced the pressure on

\footnotetext{
${ }^{7}$ This may offer some 'windows of opportunity' for environmental and conservation policies (for example, in Eastern Germany government and parliament agreed on new and rather large nature conservation areas which would not have been accepted in regular times). However, such phenomena were rather limited.
} 
the environment and gave nature a "chance to rest". However, the low use of potentially harmful inputs also reduces the motivation to design institutions and policies for sustainability. After agriculture will have been restructured, the level of input use is likely to increase again leading to growing environmental pollution. In other words, rules for sustainability and corresponding environmental policies appear to be unnecessary in the short run, although they will be urgently needed in the long run. They may find themselves in a "transformation trap". After the main period of institutional innovation has passed, it may be very difficult to change the rules and arrangements again in favour of sustainability.

- The importance of this lack of motivation may be reinforced by the fact that the preferences of people and politicians are not very much oriented towards environmental protection and sustainable resource use. They simply 'have other problems' in the difficult phase of transition such as low incomes, declining social security, lack of political stability, threats to social peace, ethnic unrest, etc.

- Since environmental protection was not given high priority in socialist societies, values and attitudes are not primarily oriented towards sustainability. The cognitive schemata or mental models of citizens and politicians are still in a process of integrating these aspects. The same is true for the knowledge system. Given the outstanding relevance of cognitive schemata or mental models for real institutional change, as substantiated by the results of the above-mentioned KATO Studies, this may be one of the most important obstacle against institutional change towards sustainability.

Finally, former communist economic and political systems usually have a deficit regarding decentralisation and participation. Many systems such as irrigation organisations were highly centralized and have to undergo fundamental transformation towards polycentricity. Similarly, the autocratic political design of the communist governments tried to avoid people's free participation in public affairs, what requires a process of learning and reorientation as an essential part of reform in those societies. Filling these gaps is particularly important for institutions of sustainability, because in the process of co-evolution mutual adjustment of ecological and social systems and the special properties of ecological systems require sufficient flexibility and scope for trial and error, as pointed out in section 1 . This requires accumulation of social capital.

\section{Social Capital and Public Participation in Transition Countries}

Social capital, in contrast to natural capital, belongs to the category of human-made capital - capital which is created by conscious effort and for which time is spent now, to increase productivity later. 
Human-made capital can be divided into physical, human and social capital (Ostrom, 2001). Institutions evolve from human interactions and their efforts to organise social life and the relations between social and ecological systems. The economy consists of many institutions (from which the market is only one) and each are specific for the purpose they serve.

Figure 2: Social Capital is Part of Human-Made Capital

\begin{tabular}{|l|}
\hline \multicolumn{1}{|c|}{ Human- Made Capital } \\
\hline $\begin{array}{l}\text { Physical } \\
\text { Stock of material resources which produces a flow of future income } \\
\text { benefiting some and may harm others, creating opportunities, constrain- } \\
\text { ing events }\end{array}$ \\
\begin{tabular}{|l|}
\hline \multicolumn{1}{c}{ Human } \\
Stock of acquired individual knowledge and skills which produces a \\
flow of future income benefiting some and may harm others, creating \\
opportunities, constraining events
\end{tabular} \\
$\begin{array}{l}\text { Social } \\
\text { groups bring to a recurrent activity which produces a flow of future in- } \\
\text { come benefiting some and may harm others, creating opportunities, con- } \\
\text { straining events }\end{array}$ \\
\hline \begin{tabular}{l} 
Stom \\
\hline
\end{tabular}
\end{tabular}

According to a report published by Lang and Serban (2000), a majority of people in Romania, Hungary and Macedonia are quite aware of environmental problems in their countries and they perceive air, water and soil pollution as main problem areas, also in agriculture. Box 5 gives some examples of agri-environmental problems and institutions in transition countries as documented by researchers of the CEESA Project. It is evident that environmental problems are a matter of public concern, and people in CEECs are willing to invest into the quality of future environments even at the expense of present wealth. There can be no doubt about the existence of social capital in transition countries, but examples show that institutions to effectively solve conflicts, e.g., land tenure and property rights problems, are still lacking (Abele et al., 2001). This lack of 
institutions is partly reflected in the expectations people have towards EU accession. Among several expectations and hopes linked to accession, people hope for stricter rules in the area of environmental protection. At the same time, confusion seems to exist regarding the form of governance of these rules. Whereas Hungarians and Macedonians are convinced that NGOs are the most efficient organisational structure for solving environmental problems, Romanians think that local governments are the best organisational and institutional solution to environmental problems.

As already pointed out in section 3, dimensions of social and cultural capital were also important for the conversion from collective to private farming during transition. What mattered for those who wanted to farm privately was access to machinery and contacts with markets, to suppliers, purchasers and bankers. Those who were in the position of strength to become commercial private farmers in post socialist villages had the adequate knowledge and good business contacts partially inherited from socialism. Successful private farm operators, of both private corporate farms and large-scale private family farms, were often socialist sector manager before 1990, because they had the necessary social and cultural capital skills to make a success of private farming (see Milczarek, 2000; Hanisch, 2000; Schlüter, 2000, i.e. the KATO privatisation studies mentioned in section 3, and also Swain, 2000).

The establishment of political instruments and the redistribution of rights and arrangements (e.g., privatisation and the legal framework) alone cannot solve the major environmental problems in agriculture. Responsibilities and duties are connected to rights and rules which are needed to effectively control and monitor. Confusion exists over the question at which level and scale these responsibilities should be located. Confusion exists also over the question of optimal institutional design patterns for solving environmental problems. This may partly be explained by a gap between legislation and practice, but a lack of experience in public participation could be another important reason. This assumption is underlined by the view of people in CEECs that national governments are spending too little effort on environmental protection, and the expectation that EU accession will bring stricter environmental rules. At the same time, there is disagreement about the level at which these responsibilities should be located (local, regional, national governments, or NGOs) (REC, 1998). 
Public participation requires a legal framework. The basic rights which are relevant to public participation include the right of access to information, the right of free expression, association and assembly, and the right to petition the government. In the early 1990s, most CEE countries established new constitutions, and these fundamental rights were granted in all CEE countries. Despite these rights and general provisions of public participation, there remains a gap between the legislative framework and the practice of public participation. This is especially evident in respect to procedures to facilitate public involvement in law- and rulemaking and in the drafting of policies, programs and plans at the national and local levels (REC, 1998).

Bridging the gap between politics and people and matching procedural and operational rules in use at the farming systems level with government policies requires answers to essential questions, such as:

1. Based on which (alternative) property rights regimes and governance structures do improved policy instruments need to be suggested?

2. Which enforcement, implementation, control, and monitoring mechanisms are adequate?

3. What are the opportunities for new institutions such as environmental cooperatives and learning by networks to come into being?

4. Which negative environmental impacts could be caused by a lack of institutions at different levels?

5. Which power constellations at the central and at the local levels influence institutional rules and arrangements?

6. Which economic incentives for nature preserving farming practices are required?

7. What measures at the farm level are adequate to improve sustainability?

8. Which trade-offs between ecological and economic goals can be expected?

9. Which adjustment problems are the farms facing regarding conversion to sustainable farming practices?

10. How do these interact with other adjustment problems which are, e.g., due to structural change and out-migration?

11. Which transaction costs occur at farm level from the necessity of measuring and monitoring agri-environmental impacts? 


\section{Box 5: Agri-environmental Problems and Institutions in Countries in Transition}

Bulgaria: The amount of water used for irrigation in the Plovdiv region has declined sharply over the past decade. The decline has been attributed to the general decline in agricultural production and decollectivisation. Decollectivisation has led to uncertainty about the organisations in charge of managing local-level irrigation works, which remained under communal property. Decollectivisation has also implied that the state-owned irrigation company deals with a large number and different types of agricultural producers, instead of the agricultural cooperatives in the past. As a consequence, irrigation canals were not maintained and deteriorated, the amount and efficiency of water use declined precipitously, and cropping structures underwent drastic changes.

Czech Republic: Bílé Karpaty has been declared a nature conservation area for its valuable habitats and species diversity. The designation involves restrictions on farming practices that are perceived as detrimental to biodiversity. The goal of protection has conflicted with agricultural production in two ways. First, unclear property rights have led to land abandonment in less fertile areas. Secondly, privatisation and expanding markets have motivated farmers to intensify cultivation on more fertile lands. The administration of Bílé Karpaty Protected Landscape Area has faced problems in an increasingly pluralistic society to enforce legally mandated restrictions on farming practices and moved from a hierarchical towards a more cooperative way to deal with local land users.

Latvia: Soil fertility has declined and the area of abandoned land has increased in Latvia over the past decade. Reduced liming has led to the acidification of agricultural soils. The decline of drainage systems maintenance has led to the destruction of drainage systems and disturbed soil moisture conditions. The deterioration of soil fertility has been associated with a general decrease in agricultural production and a shift from state and collective enterprises to small-scale and subsistence farming. As a consequence of privatisation, the farm structure has become increasingly fragmented, agricultural land abandonment has increased, and local-level drainage works have not been maintained properly.

Poland: Agricultural land has rapidly shrunk in the surroundings of Warsawa and Olsztyn. An increasing share of the land has been converted to housing land, reducing traditional agricultural landscapes and changing species compositions. Land conversion has been driven by several factors: the privatization of previous state farm land and expansion of private rights over land, an increasing demand for cheap land by people from Warsawa and Olsztyn, unprofitable market conditions for agricultural products, the desire to attract non-agricultural employment opportunities, and the hope for infrastructure improvements. County governments, empowered under the policy of fiscal and administrative decentralization, have displayed little interest to limit conversion, as they expect to gain higher tax revenues after conversion.

Romania: Irrigation management has fallen into disarray in Manastirea commune in the southern part of the country. Land had been privatized in 1991 already, but water resources and irrigation infrastructure had remained under the control of the state irrigation company. People established an agricultural cooperative to work the land, but it did not get involved in water management. The situation changed recently, when the state irrigation company was dissolved. With support by the World Bank, people now want to establish a water user association for irrigation management.

Source: Central and Eastern European Sustainable Agriculture (CEESA), Humboldt University Berlin, 2001 


\section{Bridging the Gap between Politics and People}

Matching institutions (i.e., rules, norms, rights, duties and competencies, and also arrangements, organisations, networks and procedures) between different scales is an essential prerequisite for sustainability based on the notion of co-evolution between ecological and social systems (see also Constanza et al., 2001). For this reason, social capital and public participation alone cannot contribute to achieving agri-environmental sustainability in CEECs. Building a linkage between politics and people requires initiatives from both sides (Picture 2). Merely supporting large-scale commercial farming sectors and central bureaucracies in the candidate countries, as it is largely addressed by the EU-SAPARD structural measures appears to be insufficient (Lowe, 2000). Present rural unemployment and low standards of living in rural areas in CEECs are unlikely to dissolve by these measures. The goals of multifunctional and sustainable agricultures in CEECs cannot be achieved without investing into rural development and its social infrastructure. What is needed are a range of grassroots-oriented rural development programmes, including the encouragement of diversified farming, agri-tourism, crafts and micro-businesses, training and extension, information and networking, and agrienvironmental organisations and services. This requires capacity building, institutional development and opportunities for learning by doing. Only under these circumstances people will sufficiently benefit from rural development programmes and thereby be equipped to compete in an open market after accession (Lowe, 2000).

The path towards sustainability by linking politics and citizens needs to be taken from both sides. On the one side, people are asked to mobilise creative forces by selfgovernance and participation. The area around the village of Hostetin in the White Carpathians, Czech Republic serves as a good example: different groups of society have come together to nurture a broad range of small-scale local initiatives. Initiatives have focused on developing local economies, like juice production from locally grown apples or dry fruit and jam production. Other examples of initiatives are: sewage waste treatment in reed-bed treatment plants, organic agriculture, or the re-introduction of the tradition of sheep grazing and a variety of cultural activities (Beckman, 2000; 2001).

Such activities, however, strongly rely on cooperation between a range of different partners stretching from local to international levels. Without the support from district offi- 
cials, ministries, research and business organisations and NGOs such projects will be difficult to put into practice. From this example, the benefits from investing in social capital are evident.

Picture 2: Bridging the Gap between Politics and People Requires Involvement of Citizens and Politicians

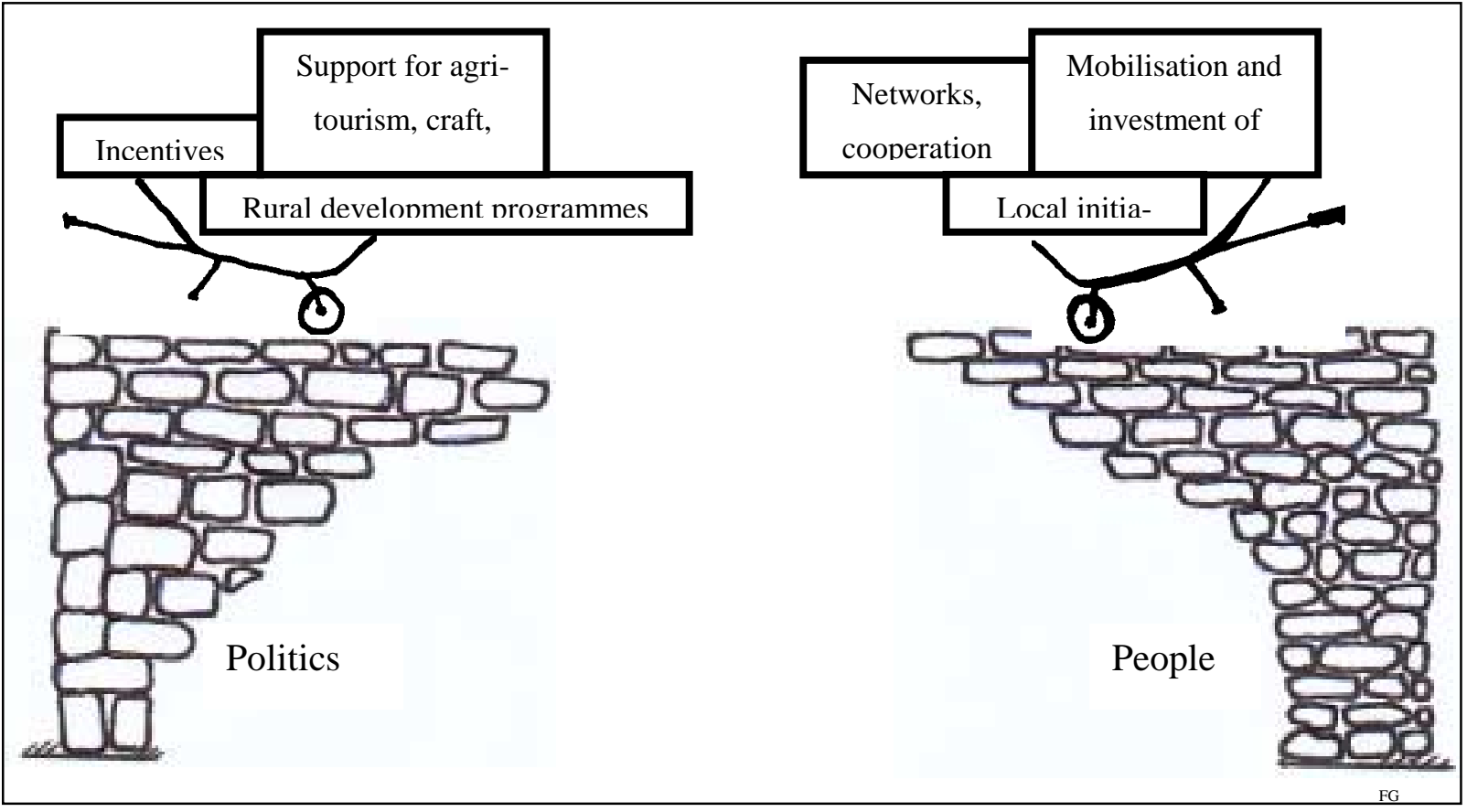

On the other hand, government is expected to implement appropriate rural development programmes and measures, as it is undertaken in Slovenia, where the government recognises the multiple functions of agriculture and supports Codes of Good Agricultural Practice and environmentally friendly farming practices. Here, sustainable agricultural policies are characterised by agri-environmental measures, de-coupled production payments for controlled measures (e.g., controlled use of fertilisers and pesticides), and investments in rural development programmes. However, essential for success is the integration of rural development policies and the coordination among different sectors, local communities and the state (Majcen, 2001). Similar to the network of actors and initiatives from different levels in the Czech example, and the success of private farm managers with good contacts, networking is regarded an absolute necessity for maintaining cultural identity and natural resources towards sustainability in an age of globalisation and trade liberalisation. 
Crafting policies in Brussels and in the national capitals of the accession countries is an important task. Nevertheless, these policies are sentenced to failure if crafting institutions with local involvement is not given as much importance. Bridging the gap between politics and people also means knowing the local circumstances for which policies are made and allowing for institutional choice. Who is eligible to make decisions? What actions are allowed or constrained? What procedures must be followed? What information must be provided or not? What payoffs and costs are assigned to people's actions? All these questions require rules in use known by everybody using them - rules which permit or forbid and are actually used, monitored and enforced when individuals make choices about actions they will take (Ostrom, 1992). Such institutions, rules which relate to people's everyday lives and work, are essential because they shape human behaviour through their impact on incentives.

To offer farmers appropriate incentives is crucial for policies to be effective. Incentives are more than just financial rewards and penalties. They are positively or negatively perceived and expected changes in outcomes resulting from particular actions. On the one hand, incentives stem from perceived technological means for farming activities (machines, inputs, etc.). On the other hand, incentives origin from individual as well as commonly held cultural values and shared mental models that people assign to certain actions and outcomes. Appropriate incentives must be able to 'touch' these sources of incentives because they lie at the heart of what motivates people. Appropriate incentives therefore need to be able to relate or to enhance the farmer's pride, e.g., by promoting them to 'stewards of the land', acknowledging the public services they provide in one way or another. Farmers and the rural population need to be given the feeling that their participation can actually 'make a difference'. Image, prestige, power or other opportunities to make oneself distinct from others; satisfaction in social relationships, desirable working conditions and sufficient incomes are other examples for where to invest in adequate incentives (some of these traditions and experiences may have been forgotten to hastily after transition). Changes in formal institutions therefore do not automatically lead to changes in rules for everyday use, and they certainly do not need to lead to corresponding changes in incentives. Without knowing how formal rules and regulations from 'above' are perceived by people working on and living from the land and without 
knowing how they fit into the specificity of the local social and economic context, policies have little chances to be useful.

What does 'bridging the gap between politics and people' mean in the context of the CAP and its environmental reforms? In a short term perspective it appears as if the reform of agricultural policies is primarily about shifting funds from the first to the newly created second pillar of the CAP. However the institutional consequences go far beyond. Bridging the gap between politics and people requires not only policy instruments to integrate the environment into the CAP but also new institutions for policy formation and implementation (Hagedorn, 2001a; Hagedorn et al., 2001b). The difficulties of dealing with these CAP reforms are illustrated by the example of cross-compliance (see below).

It is well-known that sustainable rural infrastructures require appropriate institutional arrangements. But how do these governance structures need to be designed? Where and at which level are different kinds of governance structures useful, and where do they tend to have adverse effects on the environment? Empirical evidence shows that blueprints or universal rules for optimal institutional design mechanisms are less useful. Instead, design principles which recognise the features and functions of social and ecological systems of each specific situation can be applied. These design principles refer to the question of how people can best be organised to achieve desirable outcomes. Siy (1982) identified following design principles:

- Incentives and sanctions are needed to promote long-term participation and involvement in group tasks in order to avoid 'free riding'.

- The commitment of the group members can be maintained if individual obligation is assigned in proportion to benefits derived by each member from the group activity.

- Organisational principles need to be practicable according to certain types of physical arrangements (e.g., maximum decentralisation is not feasible within a system that requires close coordination between sub-units).

- Adequate procedures for assigning and assessing members' contributions need to be found.

- The group needs to be able to generate the resources which it requires for its continued operations. These resources include direct inputs for providing the good or service and resources required to enforce agreements, procedures and regulations. 
Farmers provide and produce different private goods, but also public goods. Which institutional arrangements serve best to maintain and acknowledge such provision and production activities? Whereas much thought has been put into the question of how to arrange production activities, far less is known about how to finance the operation, maintenance and monitoring of public goods or services. Financially, acknowledging for these provisions is complicated by the nature of the goods and services being provided collectively. NGOs must rely on the user's willingness to pay for financing these services and governments can utilise the instrument of direct payments or taxation. Which payment vehicle will be best suited remains open to debate. However, this aspect should not be over-emphasized as money is just one of several other important incentives for the agricultural community to invest into the valuable agri-environments of CEECs. Experiences with privatisation in transition countries have shown that transition towards a sustainable economy and ecology requires more than just private ownership of land (see section 3).

Changing agricultural policies come along with implications for institutional change. A major characteristic of the transition process in all CEE countries is the change from a highly centralised to a decentralised system. The centralistically designed systems of the socialist era created a substantial lacuna in effective organisation. Social capital, local knowledge and experience about how to get things accomplished that require collective action had been replaced by directives, rules and default values - nevertheless they played a very important role in the system' niches. People developed skills in serving the system and circumventing it. The frequent success stories of the fulfilment of production targets in socialist times somehow resembles the frequent reports of successful compliance with EU directives. While certainly lacking well-grounded evidence this comparison wants to highlight the mismatch of institutions between the previously mentioned bottom-up initiatives and public participation and the current practice of topdown EU policies.

A current political example already mentioned above may illustrate this mismatch. The big hope connected to cross-compliance is that distributional and environmental objectives could be achieved by one policy, by adding new (environmental) objectives to the already existing instrument of direct payments. As direct payments - introduced as a 
temporary compensation for the positive income effects lost by the reduction of price support - can no longer be justified in the long run, obviously this solution serves the purposes of the political actors best as it provides new legitimisation to an old instrument (Hagedorn, 2001a; Hagedorn et al., 2001b). However, whereas direct income transfers are easily organised in a centralist and hierarchical way, decision-making on environmental standards 8 require decentralised approaches. Therefore, implementation of environmental standards require new mechanisms of administration, monitoring and control, participation, conflict resolution and learning. As the appropriate institutions for these tasks cannot be known beforehand, the design of and the choice between different institutional arrangements has to be considered as a part of the process. This again requires sufficient scope of action for the evolution of new institutions instead of only shifting competencies within existing institutional structures (the federal system) from higher to lower levels. This example shows that there are organisational tasks which can be efficiently handled centralistically (e.g., direct payments as an element of agricultural incomes policy) and others which require polycentric structures (e.g., integrating the environment into the CAP). Obviously, it is a relevant question at which scale institutionalisation and organisation should take place?

Another example refers to the speed of legislative harmonisation with the EU environmental acquis and the level of formal compliance. Although this differs from one CEE country to another, in all these countries new environmental legislation has been or is being passed in order partly to signify a break from the past pattern of overly detailed legislation combined with ineffective implementation, and partly to bring legislation into line with EU norms, in anticipation of future EU membership (Caddy, 1997; Zellei, 2001). The process of establishing environmental legal systems in CEE countries showed that environmental legislation played a more political rather than substantial role in the process of legislative approximation. The government role was decisive in creating and implementing legal acts, while the public was deprived of its role to influence and participate. Public support, understanding and willingness to comply with the enacted regulations were not seen as important in creating an effective legal system. Establishing environmental regulations was not necessary to ensure immediate im-

${ }^{8}$ Cross compliance means that direct payments are made conditional upon social and environmental criteria/standards. 
provement of economic entities, but rather to fulfil intellectual wishes and political needs (REC, 1996). Accordingly, they were usually not supplemented with effective implementation mechanisms. The implementation and enforcement of existing law continues to be a major concern in the CEECs (Zellei, 2001).

\section{Conclusions}

During the process of transition and accession towards sustainable agri-environments there are several relations which are important to consider and which we have characterised in this paper. These relations are between

- ecosystems and social systems

in general and can be subdivided into relations between

- people, their institutions (rules in use, governance structures) and agroecosystems

- national policies, politics and people in CEE countries

- EU policies, people and agro-ecosystems in CEE countries

As social and ecological systems are intrinsically interwoven, shaping sustainable agrienvironments requires taking these relations and their interactions into account. Institutions of sustainability evolve at the interface between social and ecological systems. These kind of institutions are largely rules in use or working rules with which people organise every day practices for agri-environmental resource management problems such as managing irrigation and drainage systems, or maintaining biodiversity on grasslands. Allowing for the evolution and co-adaptation of institutions to actual resource management problems is essential as we do not know beforehand which institutions are most appropriate for specific resource problems. But co-adaptation also occurs within the complexity of social systems. The privatisation experience during transition in many CEECs has shown that the social, legal, political and economical embeddedness of property relations have often been overlooked.

As institutions, especially those at the embeddedness level (norms, values, shared mental models), change slowly, building institutions of sustainability is a complex task which requires time, even more under the simultaneous influence of transition. The transition process in CEE countries has particular affects on the process of institution building and it is questionable whether the task of building institutions of sustainability is given sufficient importance. E.g., it can be observed that there is a high incentive in- 
tensity for institutional change regarding the distribution of private property rights but property rights on ecological attributes of the nature components are often duties causing negative income effects. Similarly, governance structures for making effective nonprivate property rights related to sustainable resource use and agri-environmental sustainability is much more difficult and costly to achieve and therefore they are often neglected causing adverse impacts on the environment.

Although the legal framework for public participation is set in all CEE countries and although there is a potential of public concern about environmental matters and potentials of social capital in CEECs, there remains a gap between legislation and practice which can partly be explained by lacking experience in public participation and partly by lacking systems and procedures for informing the general public about government decisions. Substantial investments into social and human capital are still needed.

The enlargement process in general and the process of adopting the aquis communitaire is an additional task which is given high priority. However, these policies are sentenced to failure if crafting institutions with local involvement is not given as much importance. Bridging the gap between politics and people means acknowledging the local circumstances for which policies are made and allowing for institutional choice (from bottom-up). Institutions are required which are known by everybody using them. In the context of the Common Agricultural Policy of the EU and its shift from the first to the second pillar (Greening the CAP) it appears as if politicians merely seek new policy instruments but forget that these are likely to be ineffective without enforcement and implementation mechanisms which require appropriate institutional design. The example of cross-compliance shows that the difference between the provision and production of private goods is different from that of non-private environmental goods and services.

The evolution of institutions of sustainability is a far more complex and challenging task than initially thought, especially under transition and accession. In order to cope with the challenges we have shown the importance of institutions of sustainability and we have provided a framework for understanding, analysis and empirical evidence for the requirements needed to achieve this kind of institutional building. Last but not least achieving sustainability requires further positive analysis. In order to learn which im- 
pacts selected policies will have on the environment, we need to know more about the actual conditions and the people who deal with specific resource management problems. 


\section{References}

Abele, St. et al. 2001. Social Organisations and Their Significance for Rural Development in Transition Countries. Paper presented at the IMAD Conference "Institutions in Transition", Otocec, Slovenia, July, 13-14 2001

Bahner, T. 1996. Landwirtschaft und Naturschutz: Vom Konflikt zur Kooperation. Eine institutionenökonomische Analyse. Europäische Hochschulschriften, Reihe V, Volks- und Betriebswirtschaften, Bd. 2005. Frankfurt am Main: Peter Lang.

Beckman, A. 2000. Initiatives for Sustainable Development in the White Carpathians. Newsletter for Agriculture, Environment and rural Development in Central and Eastern Europe, Issue 9, December 2000. Institute for European Environmental Policy (IEEP), UK

Beckman, A. 2001. Growing in the Right Direction. The Future of the Precious Rural environment of CEE. The Bulletin. Quarterly Magazine of the Regional Environmental Centre and Eastern Europe 10, No .2, June 2001. Hungary, www.bulletin.rec.org

Berkes \& Folke (eds.) 1998. Linking Social and Ecological Systems. Cambridge University Press

Bowles, S. and Gintis, H. 2000. Social Capital and Community Governance. Paper for a symposium submitted to the Economic Journal

Bromley, D. W. 1991. Environment and Economy: Property Rights and Public Policy. Cambridge Massachusetts.

Bromley, D. W. 1996. The Social Construction of Land. In: K. Hagedorn (ed.): Institutioneller Wandel und Politische Ökonomie von Landwirtschaft und Agrarpolitik. Festschrift zum fünfundsechzigsten Geburtstag von Prof. Dr. Günther Schmitt. Frankfurt: Campus, pp. 21-45.

Bromley, D. W. 1998. Property Rights in Environmental Economics. In: H. Folmer and T. Tietenberg (eds.): The International Yearbook of Environmental and Resource Economics 1997/1998: a survey of current issues. Cheltenham: Edward Elgar.

Caddy, M. 1997. Hollow Harmonisation: Closing the Implementation Gap in Central European Environmental Policy. European Environment 7, 73-80

Campbell, A. 1998. Fomanting Synergy: Experiences with Facilitating Landcare in Australia. In: N. G. Röling and E. Wagemakers (eds.): Facilitating Sustainable Agriculture. Cambridge, pp. 232- 249.

Costanza, R. et al. (eds.) 2001. Institutions, Ecosystems and Sustainability. Lewis Publishers

DeGroot, R. 1992. Functions of Nature. Wolters-Noordhoff

Engels, F. 1972 (1884). The Origins of the Family, Private Property and the State. New York: Pathfinder Press

Fisk, J. W., O. B. Hesterman and T. L. Thorborn 1998: Integrated Farming Systems: A Sustainable Agricultural Learning Community in the USA. In: N.G. Röling and E.

Wagemakers (eds.): Facilitating Sustainable Agriculture. Cambridge, pp. 217-231.

Gatzweiler, F. et al. 2001. Analysing Institutions, Policies and Farming Systems for Sustainable Agriculture in CEE Countries in Transition, CEESA Discussion Paper No. 2/5/2001

Goglio, S. 1997. The Concept of Market from a Historical Point of View. In: Emergence and Evolution of Markets, Brezinski \& Fritsch (eds.), Edward Elgar 
Hagedorn, K. 1991. Public Choice and Agricultural Policy. The Case of the CAP. In: Amartya Sen (ed.): Issues in Contemporary Economics. Proceedings of the Ninth' World Congress of the International Economic Association, Athens, Greece. Vol. 3: Partha Dasgupta (ed.): Policy and Development. Houndsmill, Basingstoke, Hampshire and London: Macmillan in association with the International Economic Association, pp. 43-71.

Hagedorn, K. 1996a. Das Institutionenproblem in der agrarökonomischen Politikforschung. Schriften zur Angewandten Wirtschaftsforschung, Bd. 72. Tübingen: J.C.B. Mohr (Paul Siebeck).

Hagedorn, K. (ed.) 1996b. Institutioneller Wandel und Politische Ökonomie von Landwirtschaft und Agrarpolitik. Festschrift zum 65. Geburtstag von Prof. Dr. Günther Schmitt. Frankfurt: Campus.

Hagedorn, K. 1999. Reasons and Options for Analyzing Political Institutions and Processes. In: K. Frohberg and P. Weingarten (eds.): The Significance of Politics and Institutions for the Design and Formation of Agricultural Policy. Studies about the Agri-Food Sector in Central and Eastern Europe, Vol. 2. Edt. by Institut für Agrarentwicklung in Mittel- und Osteuropa (IAMO). Kiel: Vauk, pp. 14-33.

Hagedorn, K. 2000a. Umweltgenossenschaften aus institutionenökonomischer Sicht. In: Michael Kirk, Jost W. Kramer und Rolf Steding (Hrsg.): Genossenschaften und Kooperation in einer sich wandelnden Welt. Festschrift zum 65. Geburtstag von Prof. Dr. Hans-H. Münkner. Münster: LIT, pp. 267-291.

Hagedorn K. 2000b. What to Learn? Evaluating the Privatisation Experience in Transition. Paper presented at the KATO Symposium, November 2-4, 2000, Humboldt University of Berlin, Germany.

Hagedorn, K. 2001a. Regionalisierung von Agrarumweltprogrammen: Gründe, Konsequenzen, $\quad$ Modelle. In: http://www.wwf.de/c_kampagnen/c_landwirtschaft/c_pdf_down loads/Agrar-Umweltprogramme.pdf. Tagungsband zur Podiumsdiskussion der Umweltstiftung WWF Deutschland, des Deutschen Jagdschutzverbandes e.V. und der Humboldt-Universität zu Berlin über: "Die Agrar-Umweltprogramme. Naturschutz in ländlichen Räumen" am 22. Januar 2001 im Internationalen Congress Center (ICC) Berlin, S. 15-37.

Hagedorn, K. (ed.) 2001b. Environmental Cooperation and Institutional Change: Theories and Policies for European Agriculture. Cheltenham: Eward Elgar (forthcoming).

Hagedorn, K. et al. 2001a. Institutional Arrangements for Environmental Co-operatives: a Conceptual Framework. Paper presented at the 64th EAAE-Seminar „Cooperative Strategies to Cope with Agri-environmental Problems“, Berlin, October 27-29, 1999. In: Hagedorn, K. (ed.) (2001c): Environmental Cooperation and Institutional Change: Theories and Policies for European Agriculture. Cheltenham: Eward Elgar (forthcoming).

Hagedorn, et al. 2001b. Same Procedure as Every Year ? The Second Pillar of the CAP and the Need for Institutional Change in the German Agricultural Policy System. Paper presented at the 73. EAAE Seminar, June 28-30, 2001, Ancona, Italy

Hanisch, M. 2001. Property Reform and Social Conflict - The Analysis of Agricultural Ownership Transformations in Post Communist Bulgaria. Institutional Change in Agriculture an Natural Resources, Vol. €, edt. by Volker Beckmann and Konrad Hagedorn. Aachen: Shaker (forthcoming). 
Hann, Chris 2000. The Tragedy of the Privates? Postsocialist property relations in anthropological perspective. Max-Planck-Institute for Social Anthropology. Working Paper No. 2

Hannon, B. 1997. The Use of Analogy in Biology and Economics. Structural Change and Economic Dynamics 8: 471-488

Holling, C.S. et al. 1996. Dynamics of (Dis)harmony in Ecological and Social Systems. In: Hanna, S. Rights to Nature, Island Press

Knight, J. 1992. Institutions and Social Conflict. Cambridge.

Lang, S. and Serban, S. 2000. Greener With Accession? Report on Public Perceptions of the EU Accession Process and the Environment. Regional Environmental Office, Hungary

Loehmann, E. T. and D. M. Kilgour (eds.) 1998. Designing Institutions for Environmental and Resource Management. Cheltenham: Edward Elgar.

Lowe, P. Challenges for Rural Development in Central and Eastern Europe. Rural Areas Newslink. Newsletter for Agriculture, Environment and Rural Development in Central and Eastern Europe, Issue 9, December 2000. Institute for European Environmental Policy (IEEP), UK

Lütteken, Antonia, and Konrad Hagedorn 1999. Concepts and Issues of Sustainability in Countries in Transition. In: Country Reports on the Present Environmental Situation in Agriculture. FAO of the United Nations, REU - Technical Series 61, Rome, pp. 26-36.

Majcen, M.H. 2001. Linking Agricultural Policy and National Development Strategies. Newsletter for Agriculture, Environment and Rural Development in Central and Eastern Europe, Issue 10, March 2001. Institute for European Environmental Policy (IEEP), UK

McGinnis, M.D. 1999. Polycentricity and Local Public Economies. Readings from the Workshop in Political Theory and Policy Analysis. Michigan

Milczarek, Dominika 2000. Privatisation of State Farms in Poland - A New Institutional Economics Approach. Institutional Change in Agriculture an Natural Resources, Vol. €, edt. by Volker Beckmann and Konrad Hagedorn. Aachen: Shaker (forthcoming).

North, D. C. 1990/1992. Institutions, Institutional Change and Economic Performance. Cambridge; in German: Institutionen, institutioneller Wandel und Wirtschaftsleistung. Tübingen: J.C.B. Mohr (Paul Siebeck).

OECD 1998. Co-operative Approaches to Sustainable Agriculture. Paris.

Ostrom, E. 1990. Governing the Commons. Cambridge.

Ostrom, E. 1998. The Institutional Analysis and Development Approach. In: E. TusakLoehman and D. M. Kilgour (eds.): Designing Institutions for Environmental and Resource Management. Cheltenham UK and Northampton ME, USA: Edward Elgar, pp. 68-90.

Ostrom, E. 1999. Die Verfassung der Allmende. Die Einheit der Gesellschaftswissenschaften, Bd. 104. Tübingen: J.C.B. Mohr (Paul Siebeck).

Ostrom, E. 1992. Crafting Institutions for Self-Governing Irrigation Systems. ICS Press

Ostrom, E. 2001. Social Capital and Collective Action. Presentation for the German Bundestag. Enquete Commission on the Future of Civic Activities, June 25, 2001, Berlin

Ostrom, E. et al. 1993. Institutional Incentives and Sustainable Development. Westview Press 
Ostrom, V. and Ostrom, E. 1999. Public Goods and Public Choices. Chapter 3, In: McGinnis, M.D. (ed.). Polycentricity and Local Public Economies. Readings from the Workshop in Political Theory and Policy Analysis. Michigan

Polanyi, K. 1944. The Great Transformation. The Political and Economic Origin of Our Time. Beacon Press

Regional Environmental Office (REC) 1996. Approximation of European Union Environmental Legislation. Case Study of Czech Republic, Estonia, Hungary, Latvia, Lithuania, Poland, Romania, the Slovak Republic and Slovenia. Budapest, Hungary

Regional Environmental Office (REC),. 1998. Doors to Democracy. Current Trends in Public Participation in Environmental Decision-making in Central and Eastern Europe. Budapest, Hungary

Richter R. und E. Furobotn 1996. Neue Institutionenökonomik. Eine Einführung und kritische Würdigung. Tübingen: J.C.B. Mohr (Paul Siebeck).

Schlüter, A. 2001. Institutioneller Wandel und Transformation. Restitution, Transformation und Privatisierung in der tschechischen Landwirtschaft. Institutional Change in Agriculture and Natural Resources, Vol. €, edt. by Volker Beckmann and Konrad Hagedorn. Aachen: Shaker (forthcoming).

Schumpeter, J. A. 1942. Capitalism, Socialism and Democracy, Harper and Row, New York

Siy, R. 1982. Community Resource Management. Quezon City: University of the Phillipines Press

Slangen, L. 2001. Sustainable Agriculture - Getting the Institutions Right. CEESA Discussion Paper No. 1/2/2001

Sugden, R. 1989. Spontaneous Order. Journal of Economic Perspectives 3, No. 4

Swain, W. 1997. Knowledge, Transaction Costs and The Creation of Markets in PostSocialist Economies. In: Emergence and Evolution of Markets, Brezinski \& Fritsch (eds.), Edward Elgar

The Bulletin, Quarterly Magazine of the Regional Environmental Centre and Eastern Europe 10, No. 2, June 2001. Hungary, www.bulletin.rec.org

Van Woerkum and N. Aarts 1998. Communication between Farmers and Government of a Nature: A New Approach to Policy Development. In: N. G. Röling and E. Wagemakers (eds.): Facilitating Sustainable Agriculture. Cambridge, pp. 27280 .

von Benda-Beckmann, F. and K. 1999. A Functional Analysis of Property Rights with Special Reference to Indonesia. In: T. van Meijl and F. von Benda-Beckmann (eds.): Property Rights and Economic Development; Land and Natural Resources in South-East Asia and Oceania. Kegan Paul Int., London

Weimer, D.L. 1997. The Political Economy of Property Rights. In: Weimer, D.L. (ed.): The Political Economy of Property Rights. Institutional Change and Credibility in the Reform of Centrally Planned Economies. Cambridge: Cambridge University Press, pp. 1-14.

Williamson, O. E. 1996. The Mechanisms of Governance. Oxford: Oxford University Press.

Woodhill, J. and N. G. Röling 1998. The Second Wing of the Eagle: The Human Dimension in Learning our Way to More Sustainable Futures. In: N. G. Röling and E. Wagemakers (eds.): Facilitating Sustainable Agriculture. Cambridge, pp. 4677.

Zellei, A. 2001. Challenges for Agri-Environmental Policies in CEE Countries. CEESA Discusion Paper No. 3/6/2001, ISSN 1616-9166

Sustainable Agriculture in Central and Eastern European Countries (CEESA) 
Zimmer, Y. 1991. Überlegungen zur nicht-staatlichen Bereitstellung des beschränkt öffentlichen Gutes ,,bäuerliche Kulturlandschaft““. Zeitschrift für Umweltpolitik und Umweltrecht 14, Nr. 3.

Zimmer, Y. 1994a. Naturschutz und Landschaftspflege - Allokationsmechanismen, Präferenzanalyse, Entwicklungspotentiale. Kiel.

Zimmer, Y. 1994b. Zur institutionellen Regelung von Naturschutz und Landschaftspflege im Bereich der Landwirtschaft - private Güter, öffentliche Güter und Club-Güter? In: Hagedorn, K. et al. (eds.): Gesellschaftliche Forderungen an die Landwirtschaft. Schriften der Gesellschaft für Wirtschafts- und Sozialwissenschaften des Landbaus e.V., Bd. 30. Münster: Landwirtschaftsverlag. 